\title{
Plan of Action for the year 2000
}
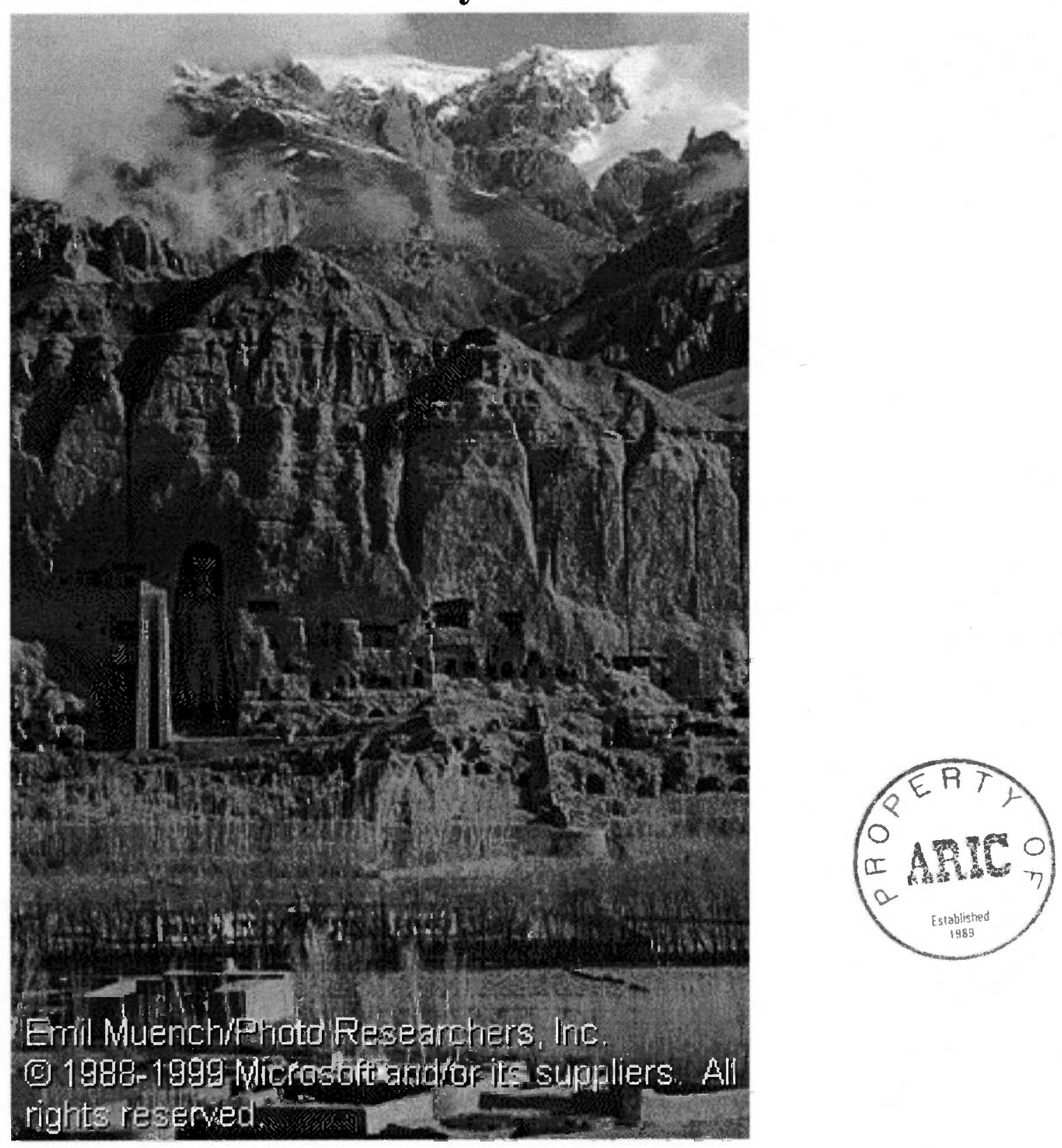

Health agencies Hazarajat 
Introduction:

\section{- The area}

Hazarajat is the mountainous region in the centre of Afghanistan populated mainly by the Hazara tribe, a people of Turkic and Mongolian ancestry. The Hazaras are predominantly Shiites and on both religious and tribal grounds have been repressed throughout history by successive rulers and pushed further into the inhospitable land of the central highlands. (a map of the area can be found on page 6)

The majority of the Hazaras survive as farmers although few actually own their own lands and many, even today, follow a tradition of semi-feudalism. Farming methods in Hazarajat are similar to those employed throughout Europe 700 years ago with the added hardship of there being a constant shortage of water for irrigation. It is hard, back breaking work and in areas such as Lal in Ghor province the threat of poor crops and food shortages is ever present.

In addition to the problems posed by the natural environment, the population of Hazarajat has especially in the last three years suffered very much from the ongoing war in Afghanistan. During 1997 and the first eight months of 1998, the area was subjected to a blockade by the Taliban who at that time controlled most of the roads leading into Hazarajat. At the same time the roads from the north, not under Taliban control at that time, were closed most of the time due to security problems. This resulted in severe shortages in food materials and other essential commodities in most parts of Hazarajat. In September 1998 the Taliban took control of Hazarajat after having conquered most of Northern Afghanistan a month earlier. The roads were now open again, but especially in the northern part of Hazarajat fighting went on for a long time. The capital, Bamyan, changed hands twice in May 1999. This fighting was accompanied by a lot of looting and serious human rights violations. As a result many people especially in Bamyan and Yakaolang had to leave their homes. In those two places all offices and clinics run by aid agencies were looted at least once during the fighting. Also in other areas, such as Behsud, clinics were looted.

Even before the fighting of 1998 and 1999, health care services coverage in Hazarajat was rudimentary. The available services at that time were provided mainly by NGOs and by the Iranian Red Crescent Society. The Iranian Red Crescent Society was not able to continue its activities after the Taliban take over, the NGOs all continued. Compared to previous years however their activities were slightly reduced.

Figures for 1999 leave no doubt about the needs in terms of health care services.

Vaccination coverage (DPT3 for under ones) is estimated at $7-8 \%$, the proportion of pregnant women receiving adequate antenatal care is estimated at $4 \%$, the proportion of tuberculosis patients receiving proper treatment is estimated at $3 \%$. Some of these figures may have been slightly higher in preceding years, but they have never been substantially higher.

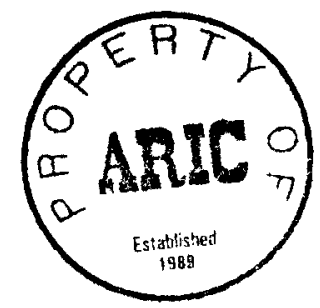




\section{- The health care actors}

Six NGOs were present in Hazarajat at the time of the Taliban take over in September 1998. In addition there was the Iranian Red Crescent Society running the district hospitals in Bamyan and Yakoalang and a clinic in Panjao. By the end of 1999 one more NGO had started working in Hazarajat, whereas the Iranian Red Crescent Society had left the area. The seven NGOs active in health care in Hazarajat are Action contre la Faim (ACF), Ibn Sina, International Assistance Mission (IAM), LEPCO, Médecins sans Frontières (MSF), Oxfam and Shuhada. ACF, Ibn Sina, MSF and Shuhada are running curative health units combined with preventive activities such as EPI and MCH. IAM and Oxfam are running mainly community based preventive health care activities, in addition IAM also runs a curative referral centre. LEPCO runs a tuberculosis and leprosy control program, most LEPCO clinics also run general curative OPDs. .

\section{- Background of common planning process}

In July 1998 a common programming workshop took place in Bamyan, under the auspices of the UN. The UN agencies involved in healthcare, WHO and UNICEF, had never been major actors in Hazarajat. However the fact that all but one of the NGOs involved in healthcare in the area agreed to join the co-ordination process seemed to be a promising start. Unfortunately the planned health care co-ordination meetings never took place, since three weeks after the workshop all international staff were evacuated from the area as a result of security concerns. In January 1999 contacts were re-established and on request of the Japanese government a plan was made for a fully integrated healthcare program in Bamyan town. Unfortunately the plan was never implemented because of a renewed outbreak of fighting in Bamyan. Informal contacts between the NGOs continued during the remainder of 1999, but no formal co-ordination meetings took place. During a workshop in March of this year senior representatives of six out of the seven health NGOs were together again and decided to revive the co-ordination effort.

The idea behind reviving the co-ordination effort was by no means to co-ordinate for the purpose of co-ordinating. There were some very practical issues. Several agencies have community based activities, all agencies want to get certain messages across to the population. Rather than to send seven different persons to the same villages, each with a different message, it was decided to develop common guidelines on health awareness messages. The same community health worker will then be able to cover all aspects and more villages can be reached. There are seven tuberculosis control centres in the area, but they reach only $3 \%$ of the target population. Climatic and geographical conditions being as difficult as they are in Hazarajat and the population being so much scattered, it is impossible to treat every TB patient in or near his home village. Similar problems are encountered in ante natal services and EPI. As a result during 1999 only an estimated 4\% of all pregnant women visited antenatal services at least twice, EPI coverage (DPT3) during the same year was estimated at no more than $7-8 \%$.

A few additional health facilities may be required, however this will not solve the problem. A much larger increase in coverage is to be expected from increasing and improving community based activities and establishing links between existing health 
facilities where they provide complementary services. All this requires a co-ordinated effort from agencies involved.

\section{- Planning strategy}

The autonomy of each of the individual agencies will remain unchallenged. This common document has been produced based on already ongoing and planned activities of each of the NGOs for the year 2000. In November of this year a similar document will be produced for the year 2001. Gradually the nature of the document should change from a compilation of individual plans to a truly common plan. The documents will serve as a guideline for the agencies involved and will be made available to new comers in the area. This way it is hoped that a maximum efficiency can be achieved in the use of scarce resources

During the year 2000 the emphasis will be on establishing links between community based activities of the agencies. Community health workers will undergo refresher courses based on commonly developed guidelines. Furthermore a common recording and reporting system will be developed, based on the systems already in use. Three coordination meetings are scheduled for this year, the first one of those already took place in March.

\section{- Requirements for the year 2000}

For the year 2000 a total of US $\$ 930,466$ is required by all agencies involved. A summary of the budget is given below:

\begin{tabular}{|l|r|}
\hline Budget item/ Description & Amount required in US\$ \\
\hline 1 Investments & 227,205 \\
\hline 2 Salaries & 341,627 \\
\hline 3 Training expenses & 14,484 \\
\hline 4 Running costs & 344,950 \\
\hline 5 Administration & 2,200 \\
\hline & \\
\hline Total & 930,466 \\
\hline
\end{tabular}


Goal : To improve the health status of the population of Hazarajat

Purpose : To improve the quality and to increase the accessibility of existing healthcare services

\section{Objectives for the year 2000:}

Objective 1 : To maintain existing health care services and increase the percentage of the population of Hazarajat reached by those services, especially women and children.

Objective 2 : To increase vaccination coverage

Objective 3 : To maintain and improve TB and leprosy control services

Objective $4 \quad$ : To improve co-ordination of health care activities

Objective 5 : To increase the level of health awareness among the population 


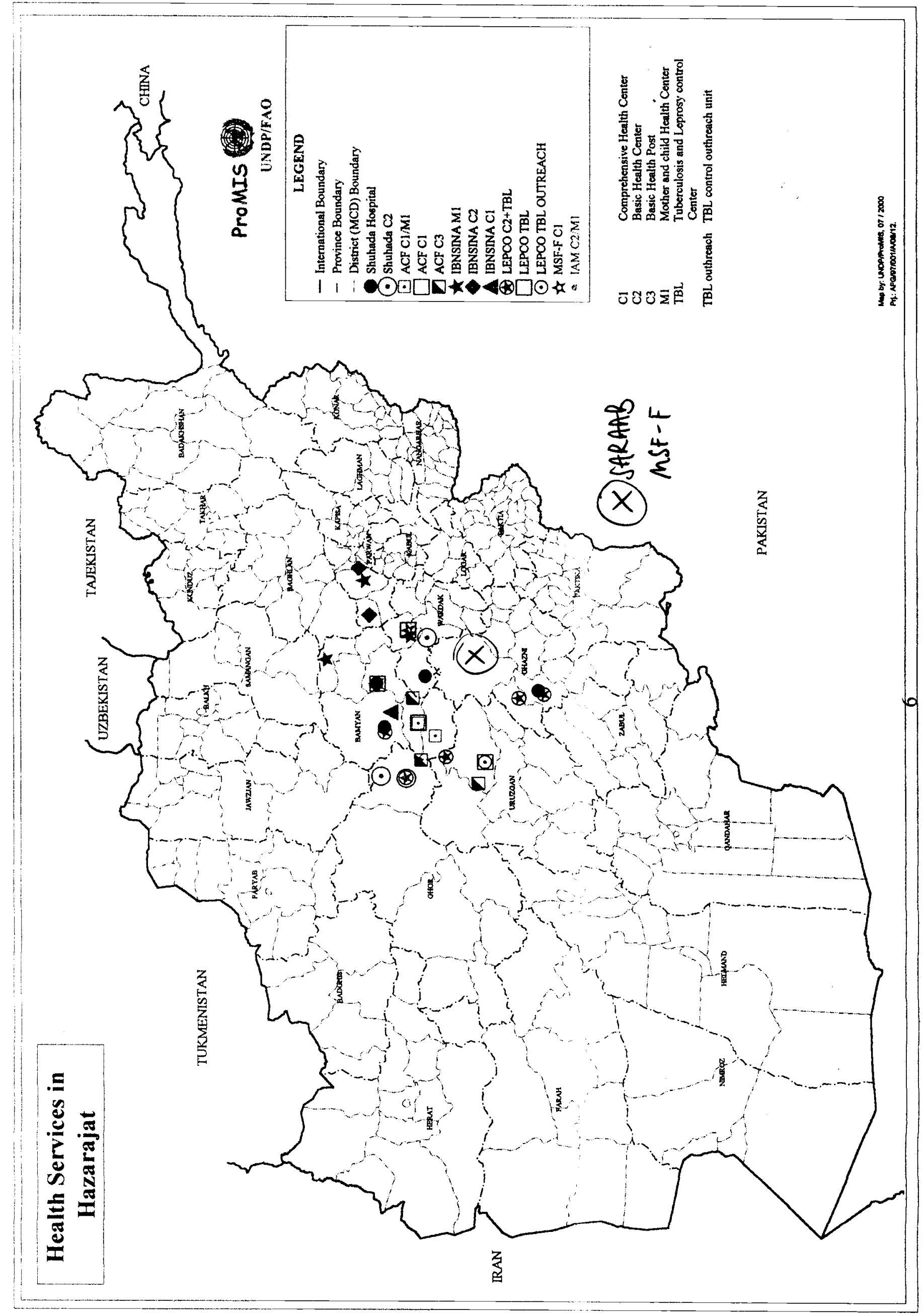




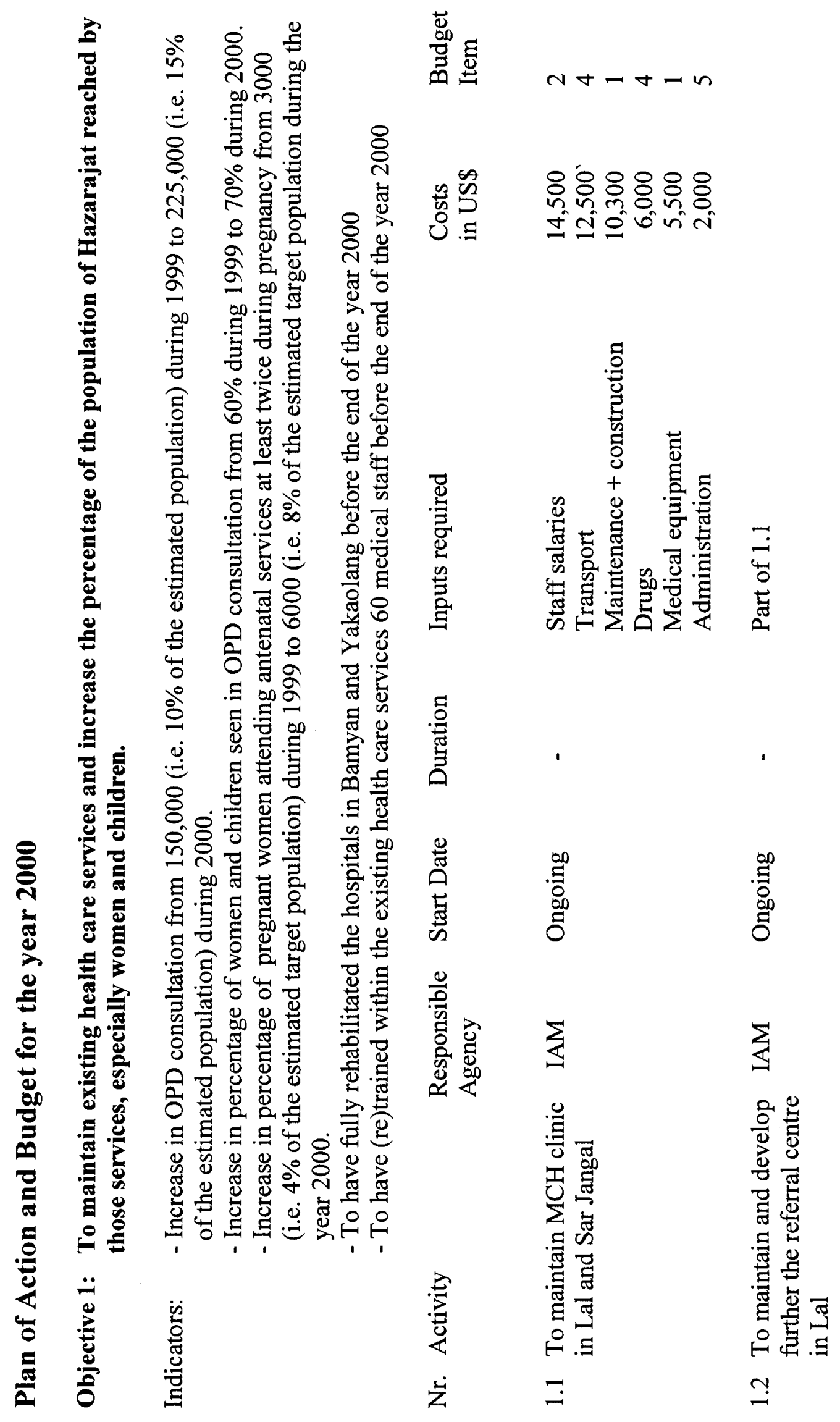


喜焉

$m m m$

ヘオオーオオ

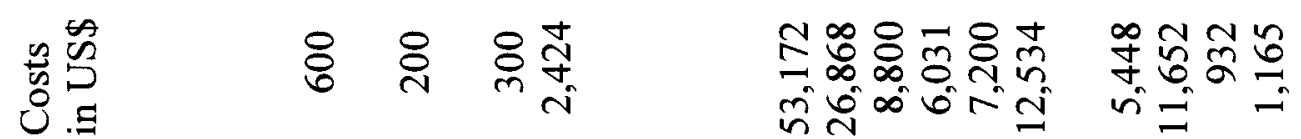

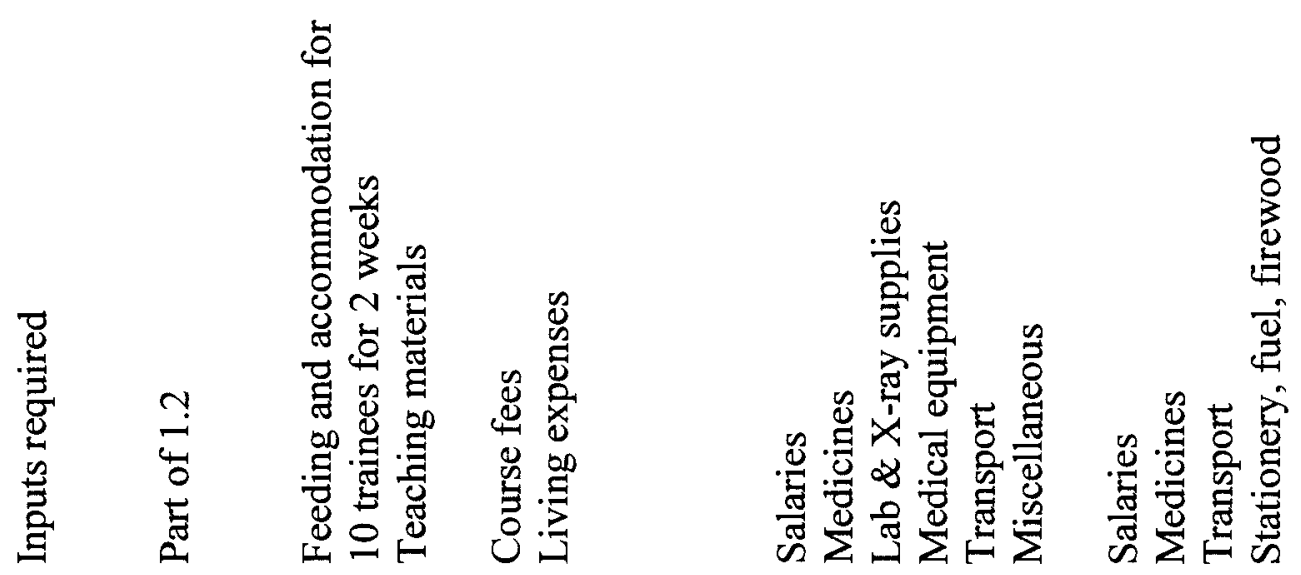

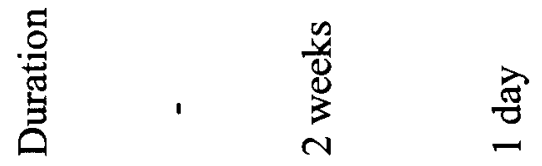

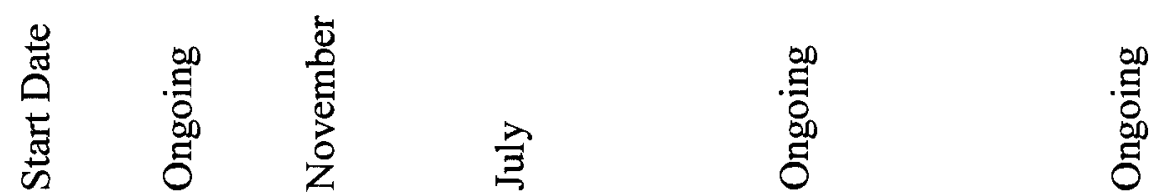

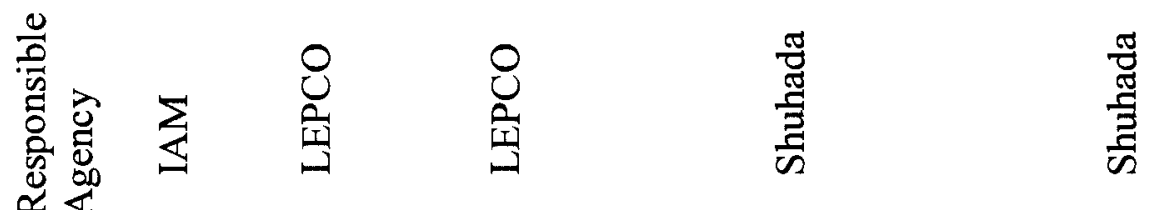

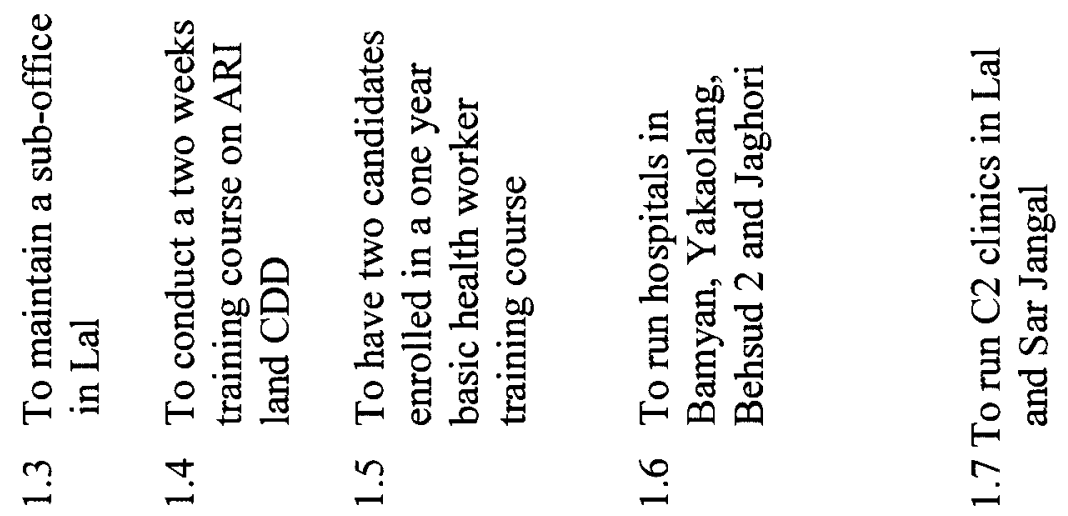


II

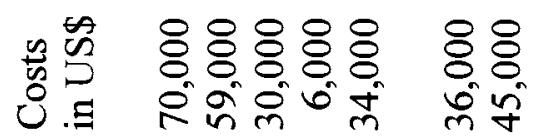

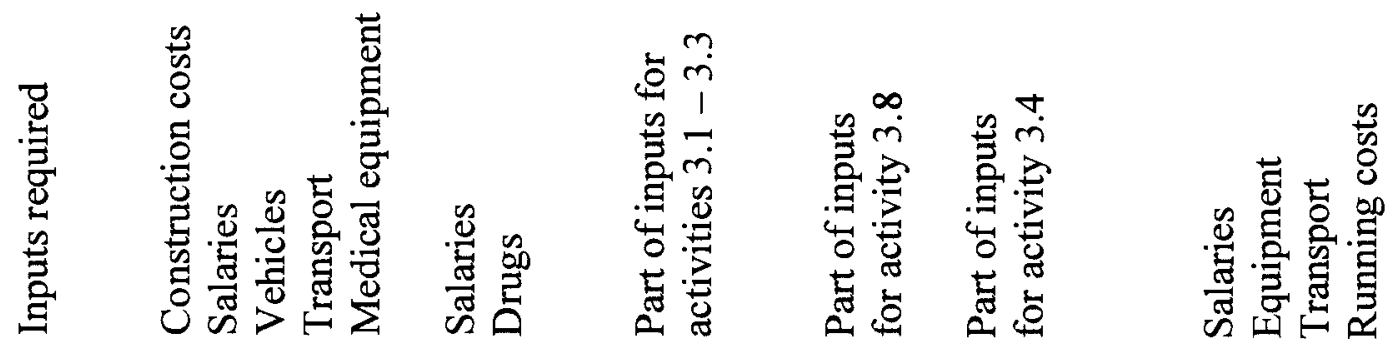

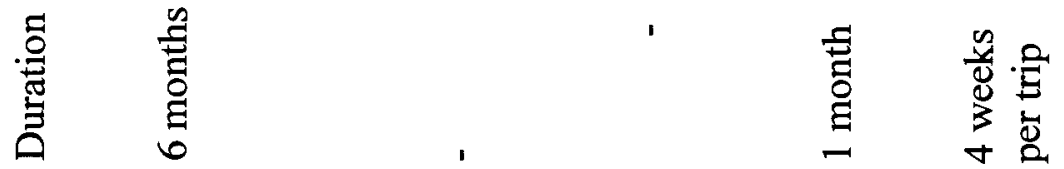

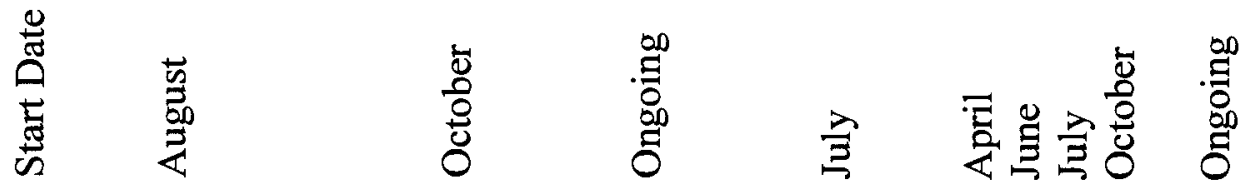

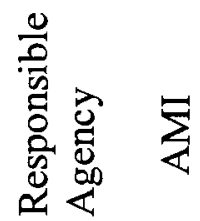

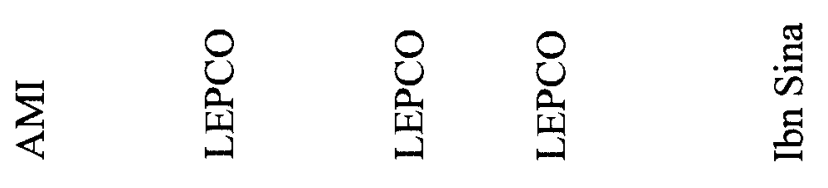

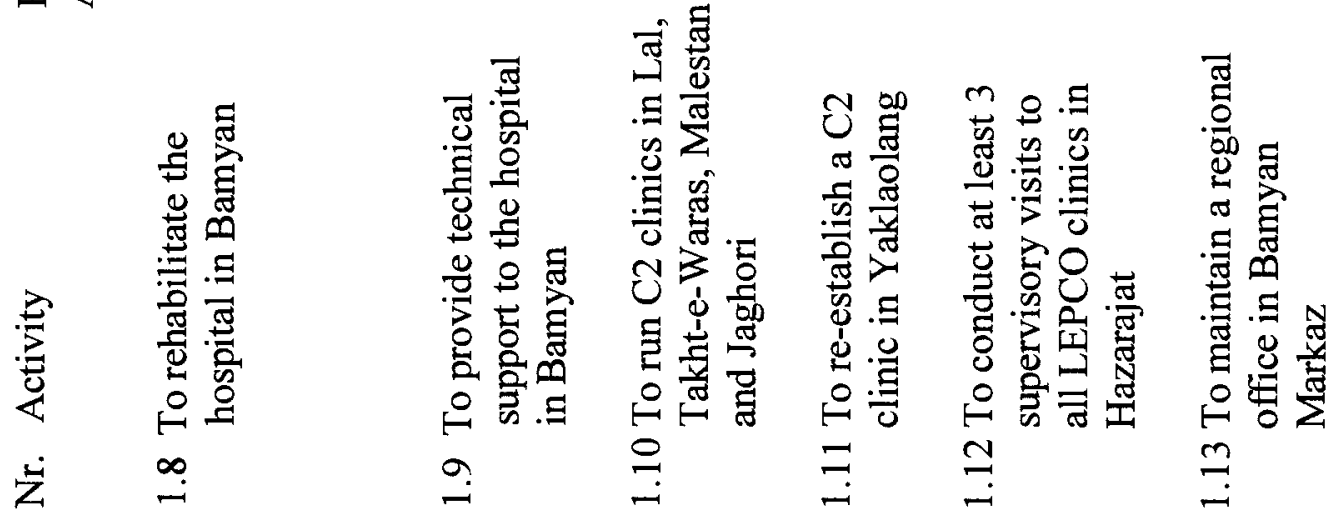


兽焉 Nナーナ

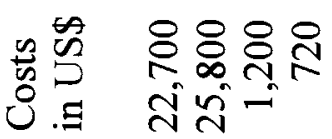

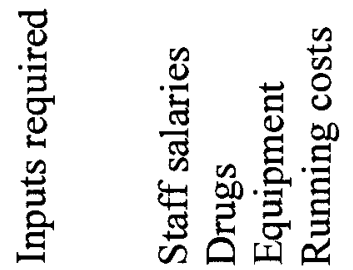

○ี

䓠

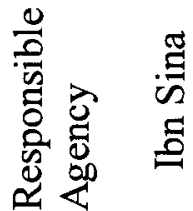

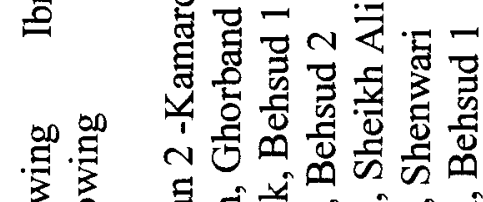

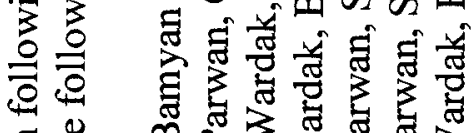

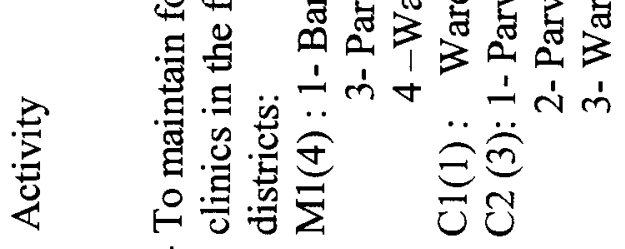

¿

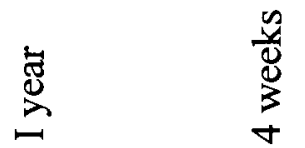

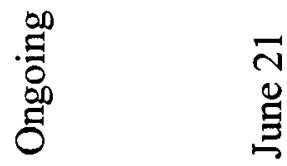

急

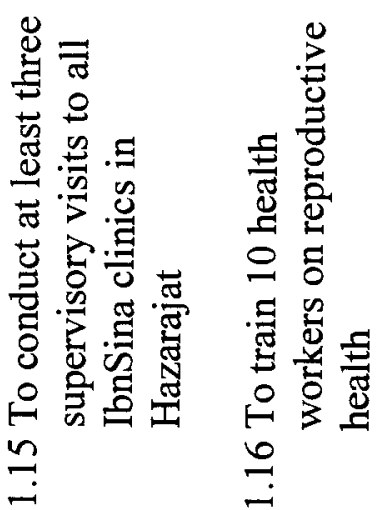


क

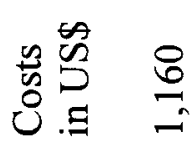

胥

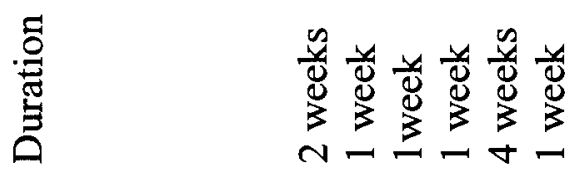

$\sum_{\frac{0}{0}}^{\frac{0}{\pi}}$

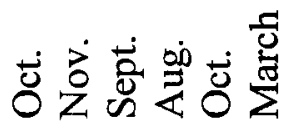

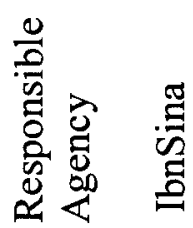

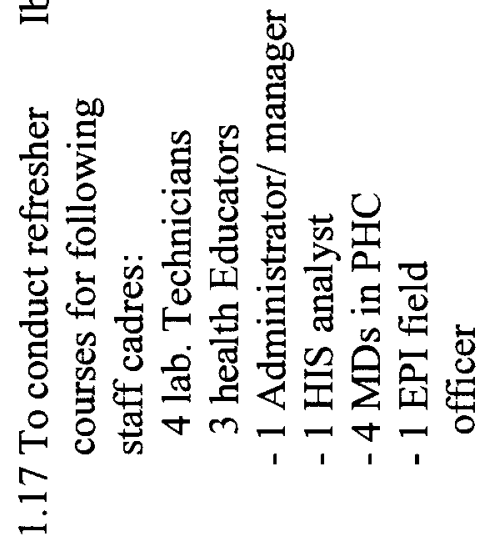

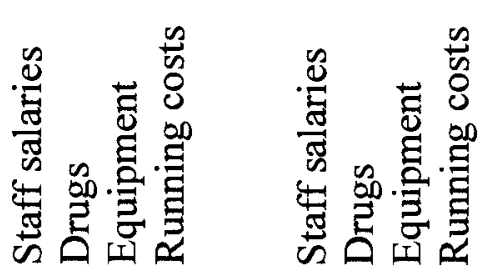

咀

茴

岁

岁

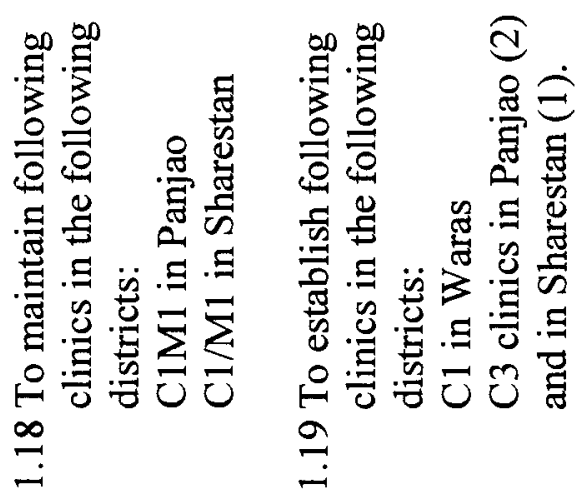




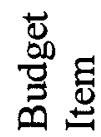

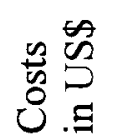

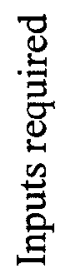

مُ

营

焉

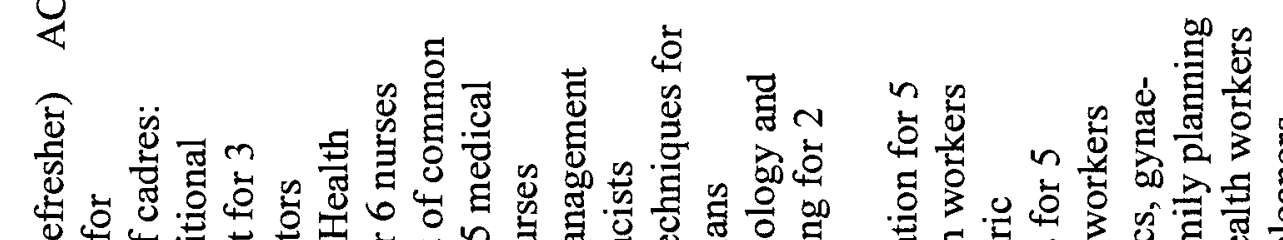

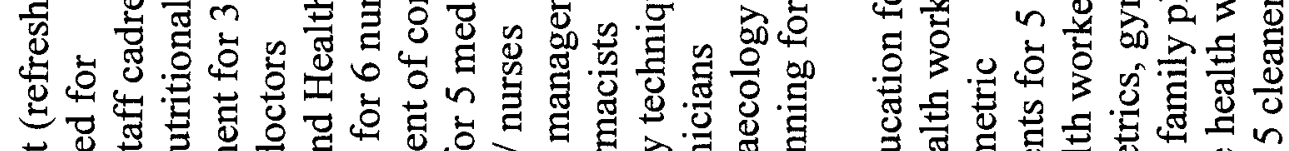

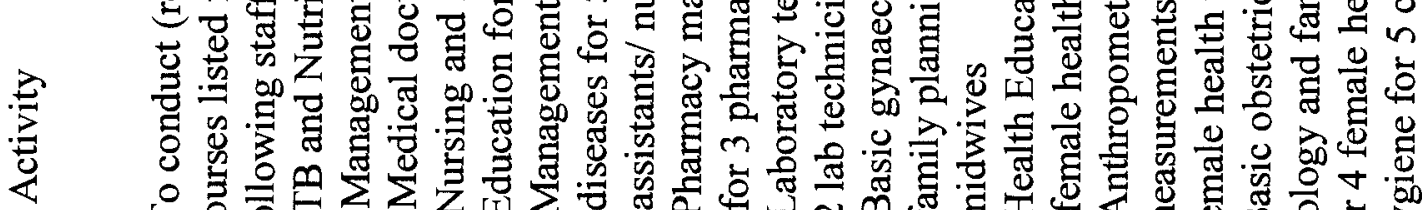

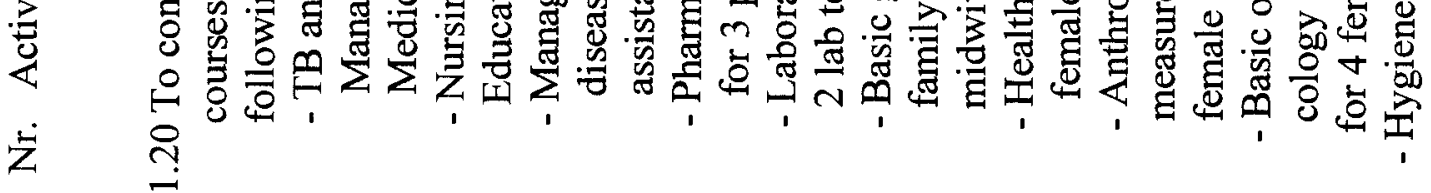




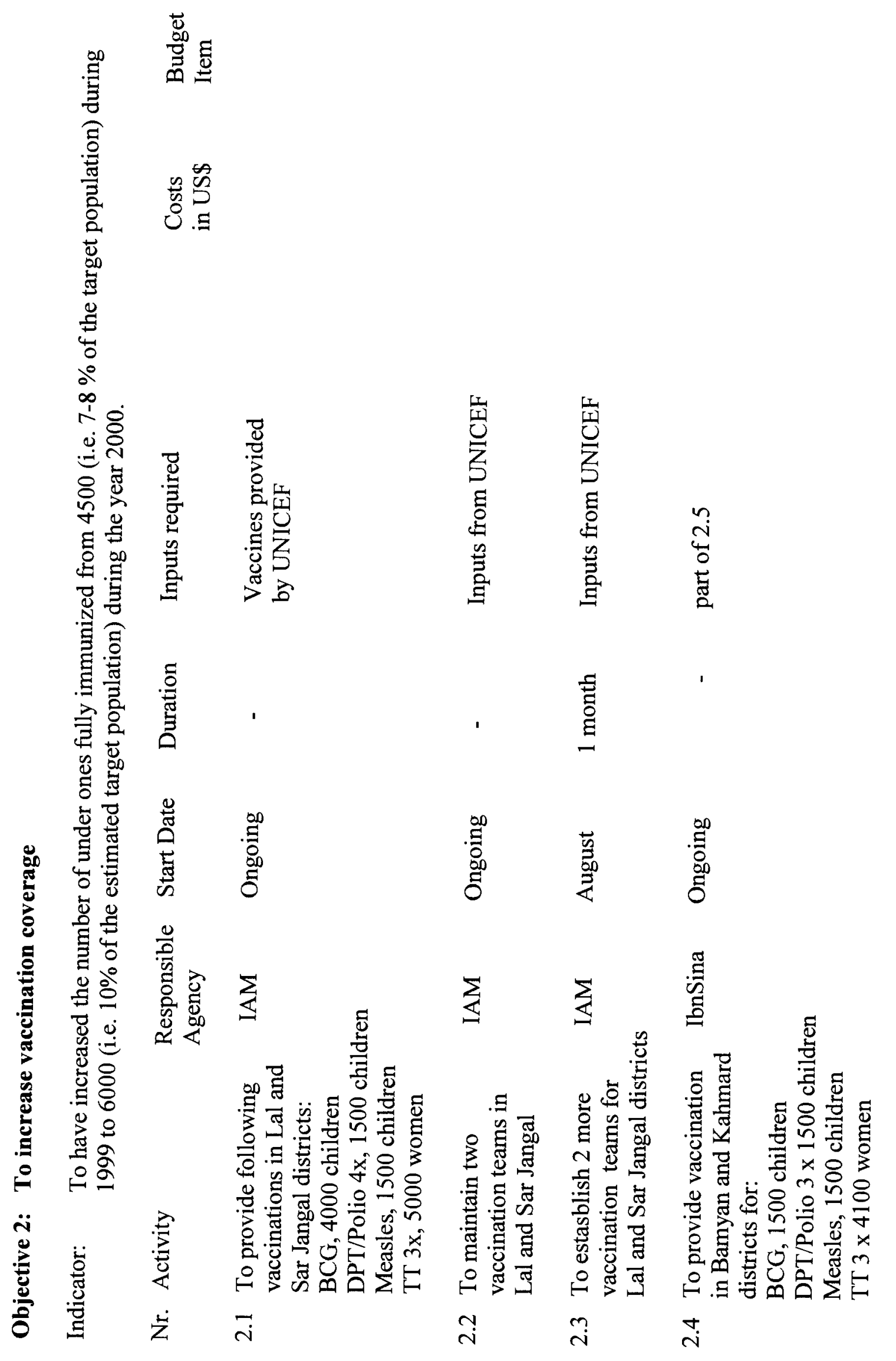




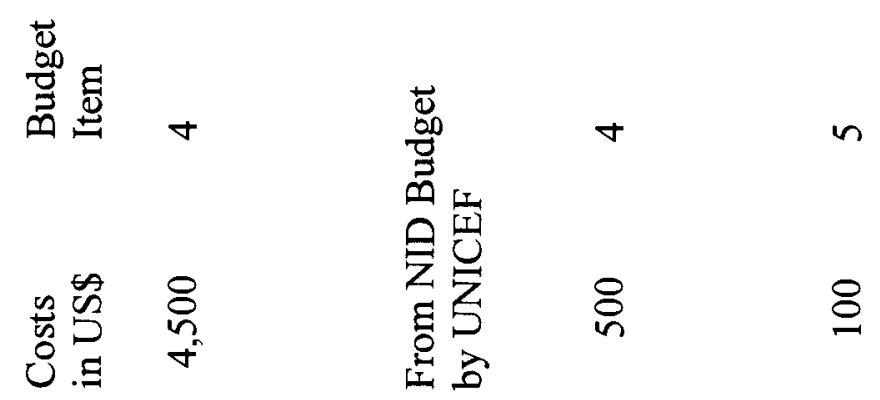

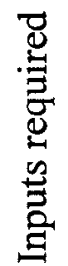

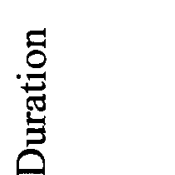

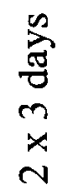

$\frac{n}{3}$

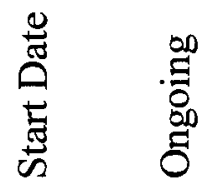

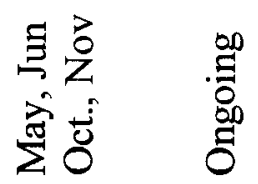

我

.0.

$\frac{2}{5}$

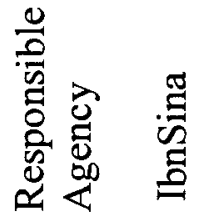

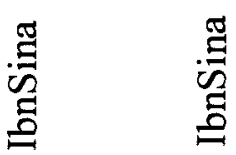

急

它

岁

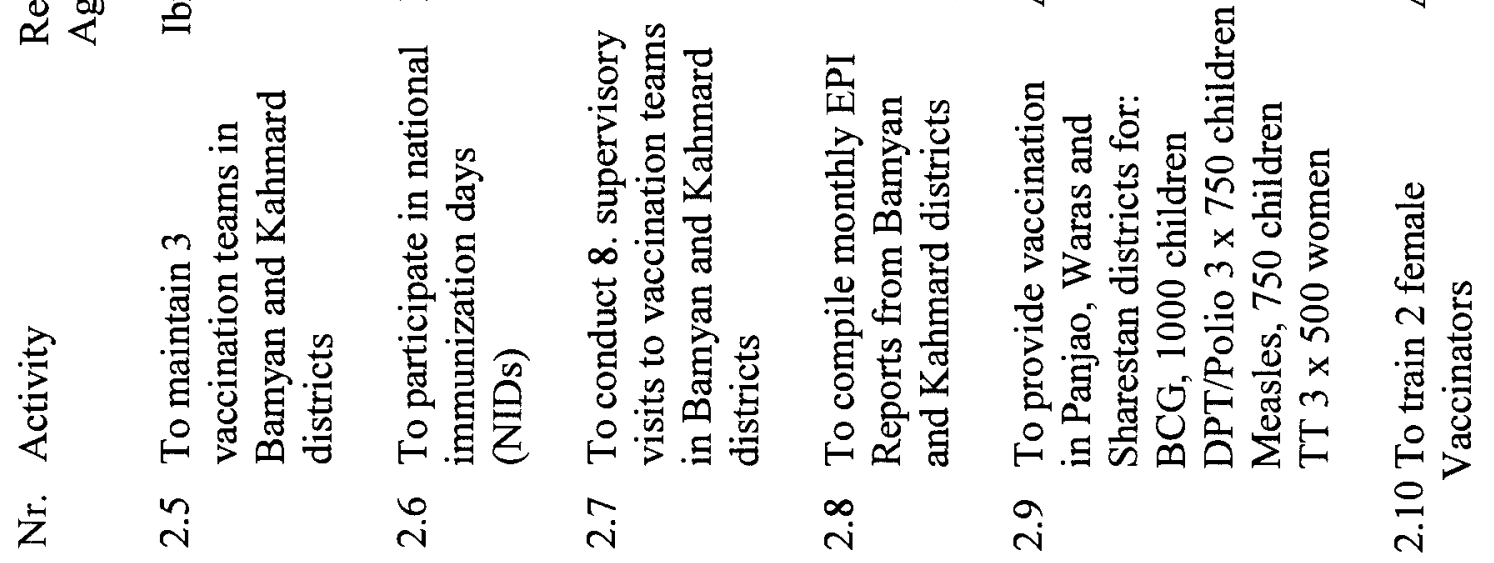




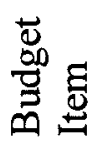

N

范点

n

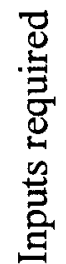

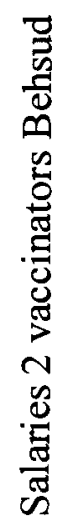

疍

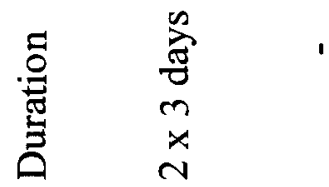

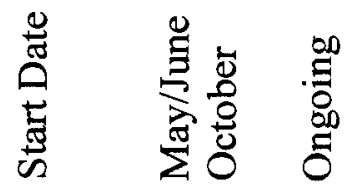

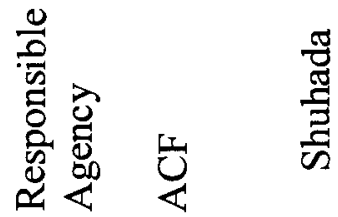

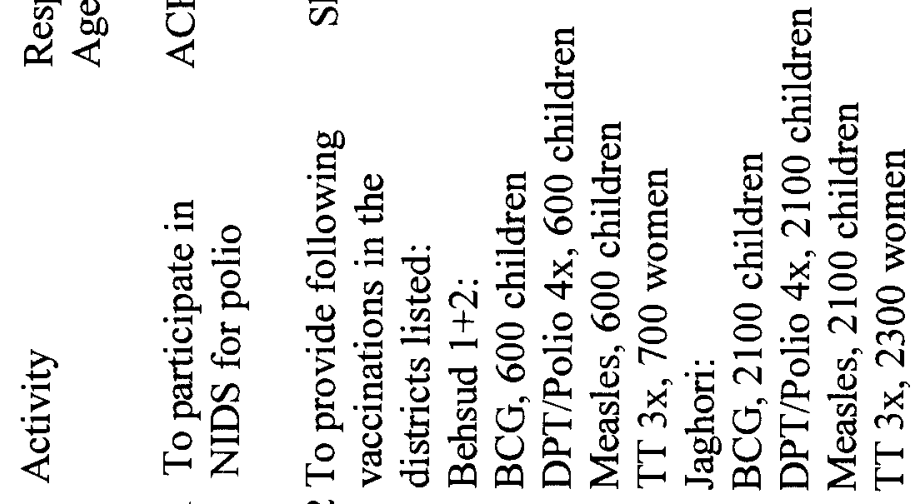

艺 


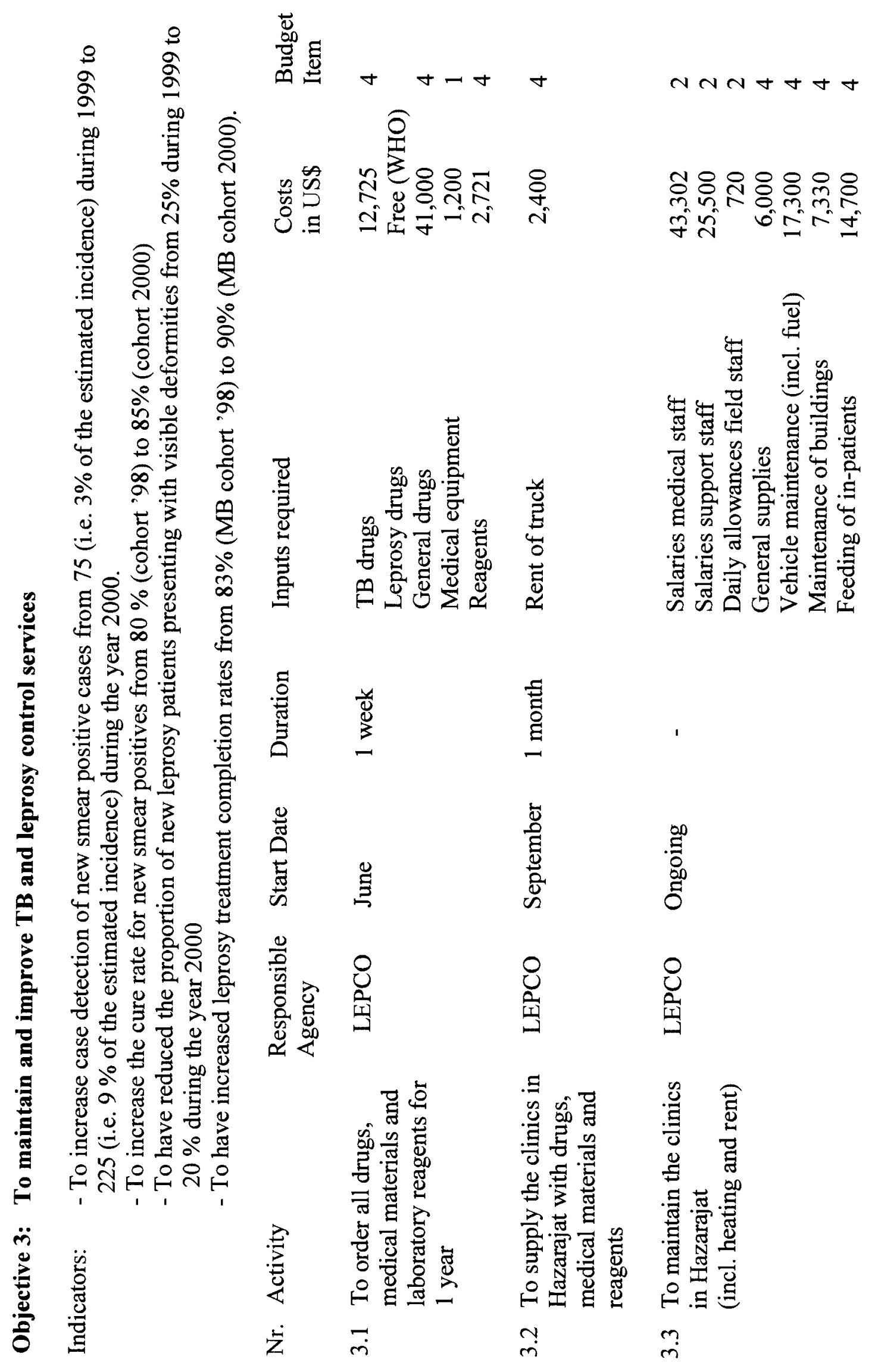


离

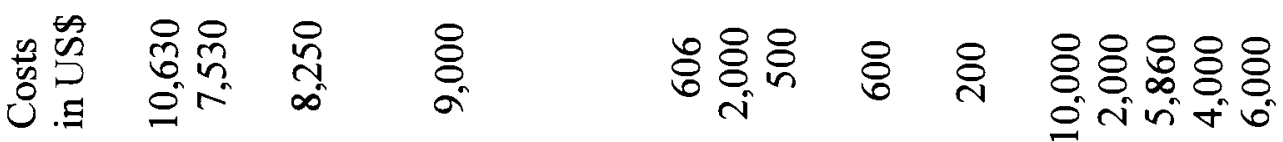

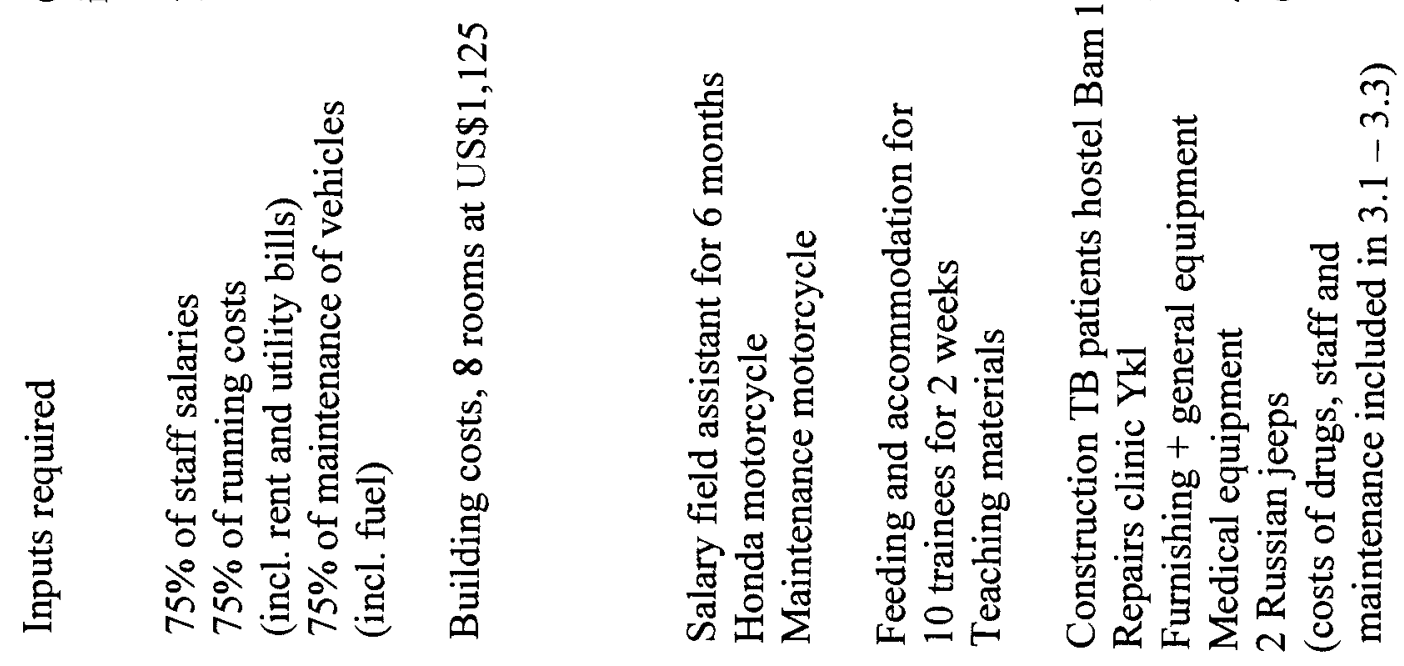

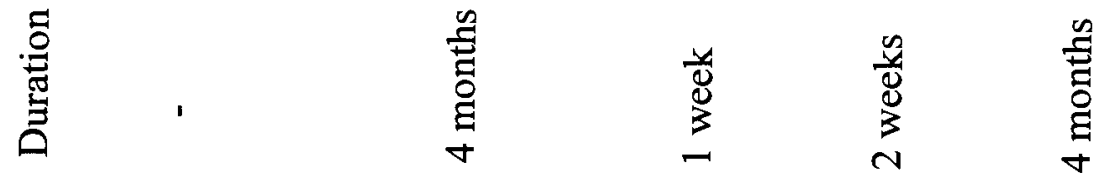

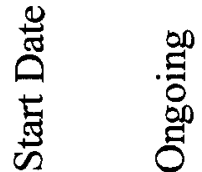

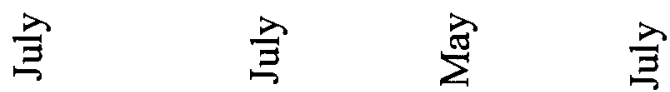

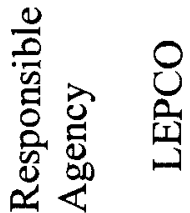

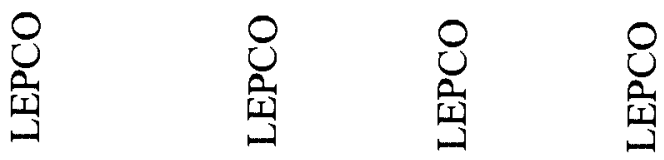

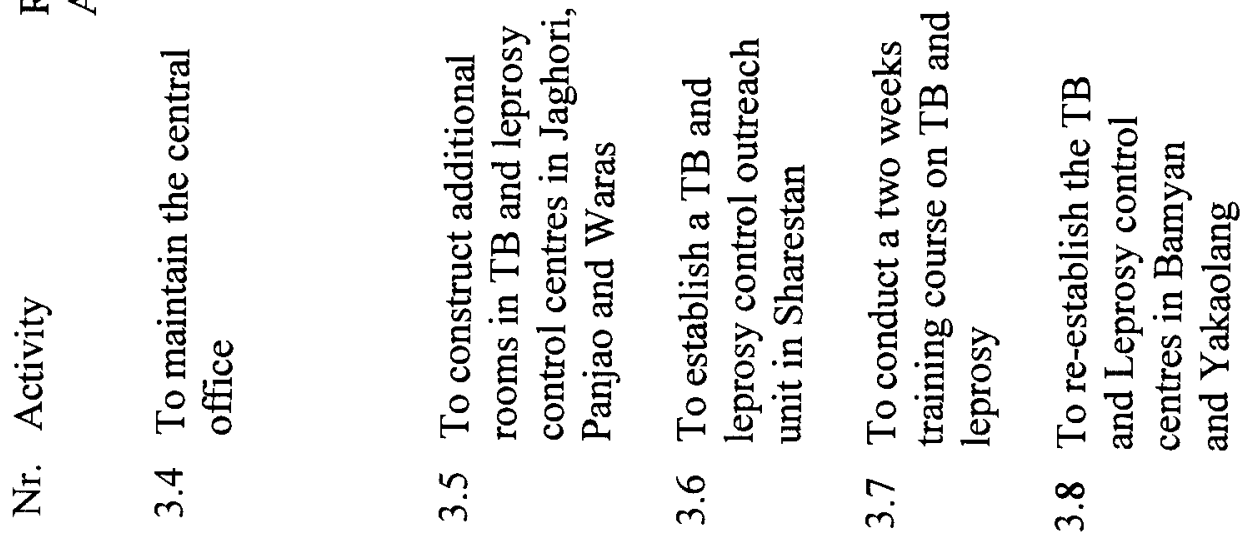




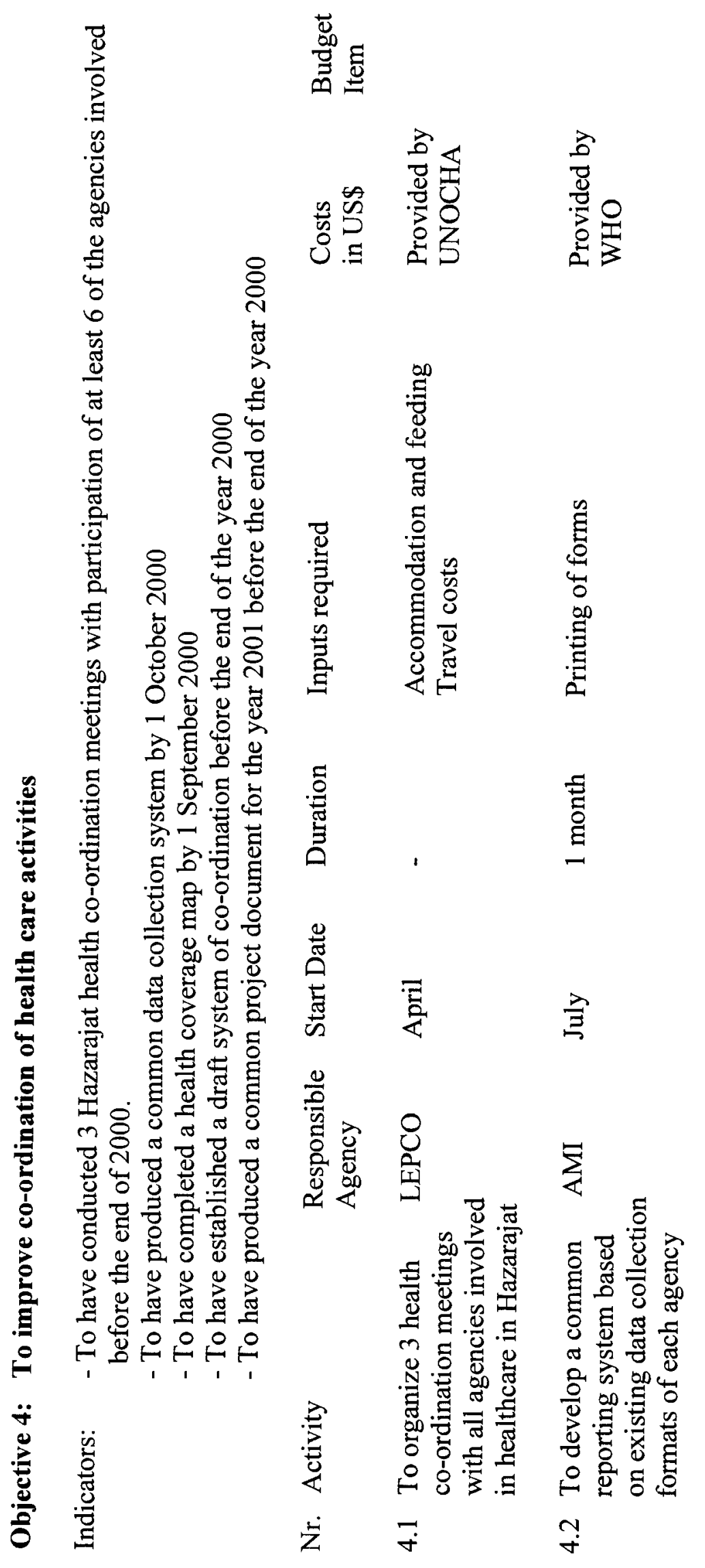




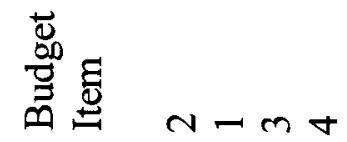

$N-m$

4

형

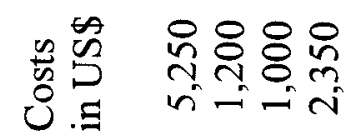

๙ิ

요 -

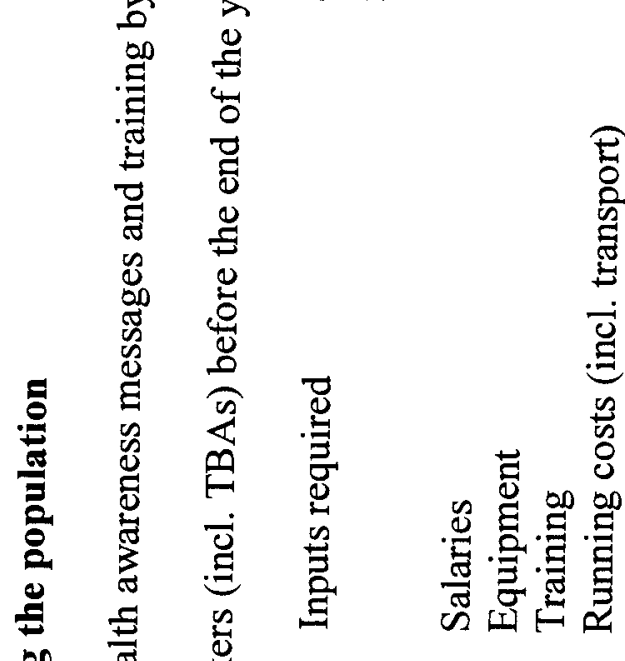

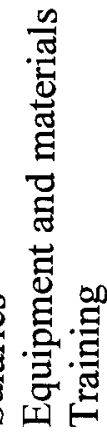

然莺

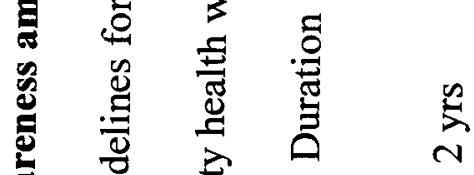

$\stackrel{2}{\stackrel{2}{2}}$

营

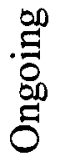

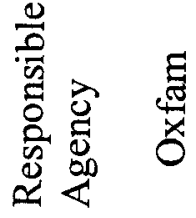

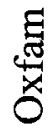

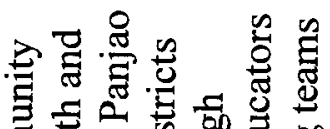

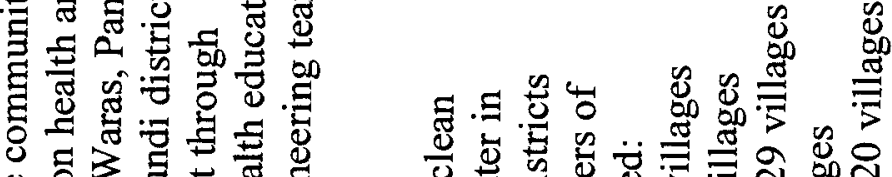

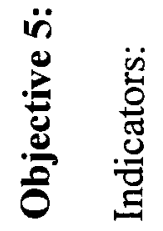

๘

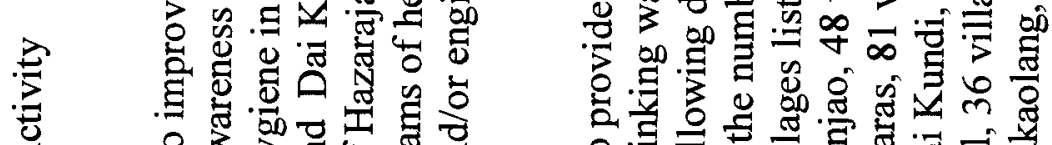

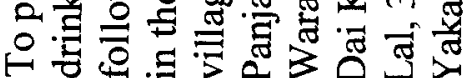

$\dot{z} \quad \dot{n}$

กั 
蔐焉

跑

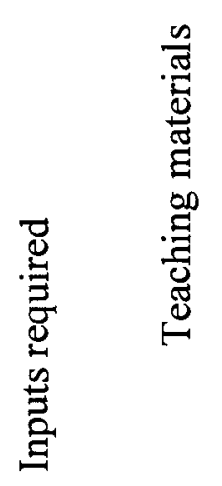

喜

章

亳高

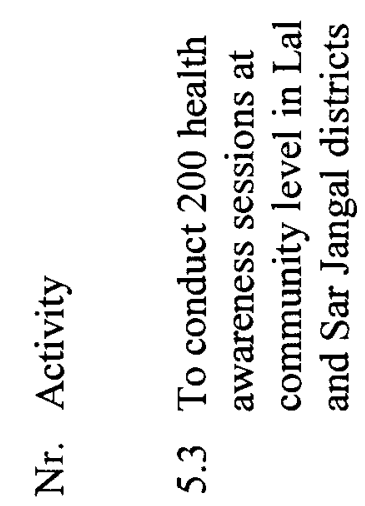

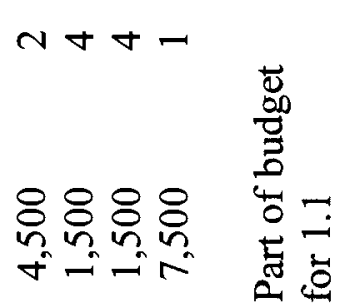

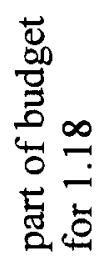

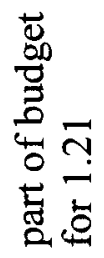
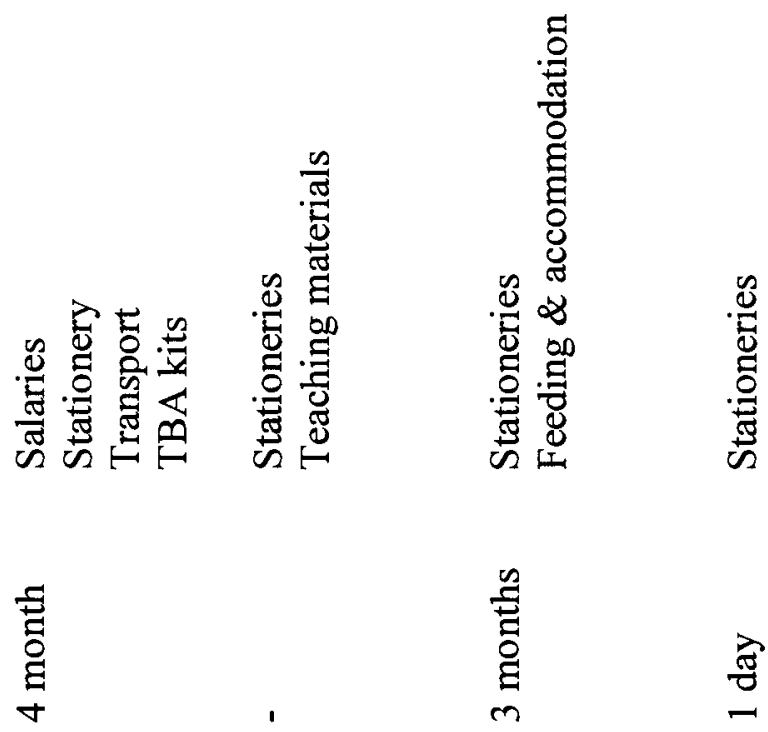

童曋

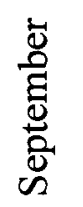

善

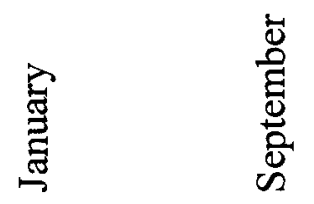

营

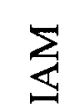

蓆

峞

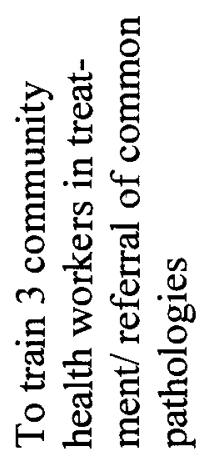

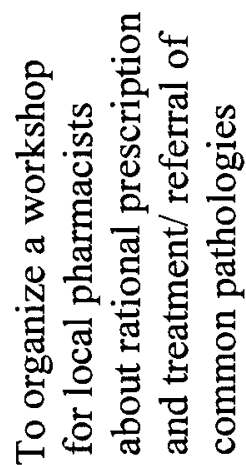

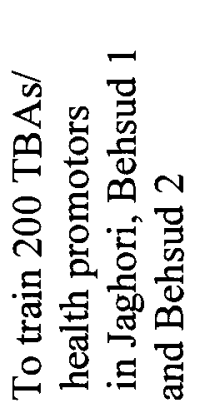

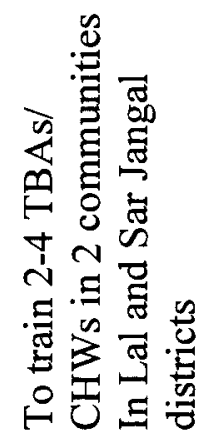

i

in 


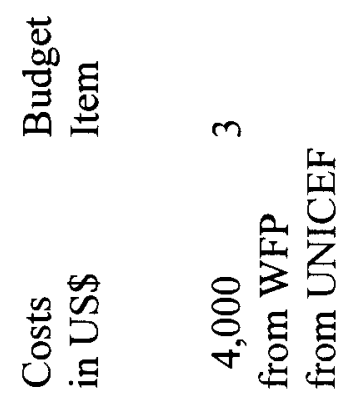
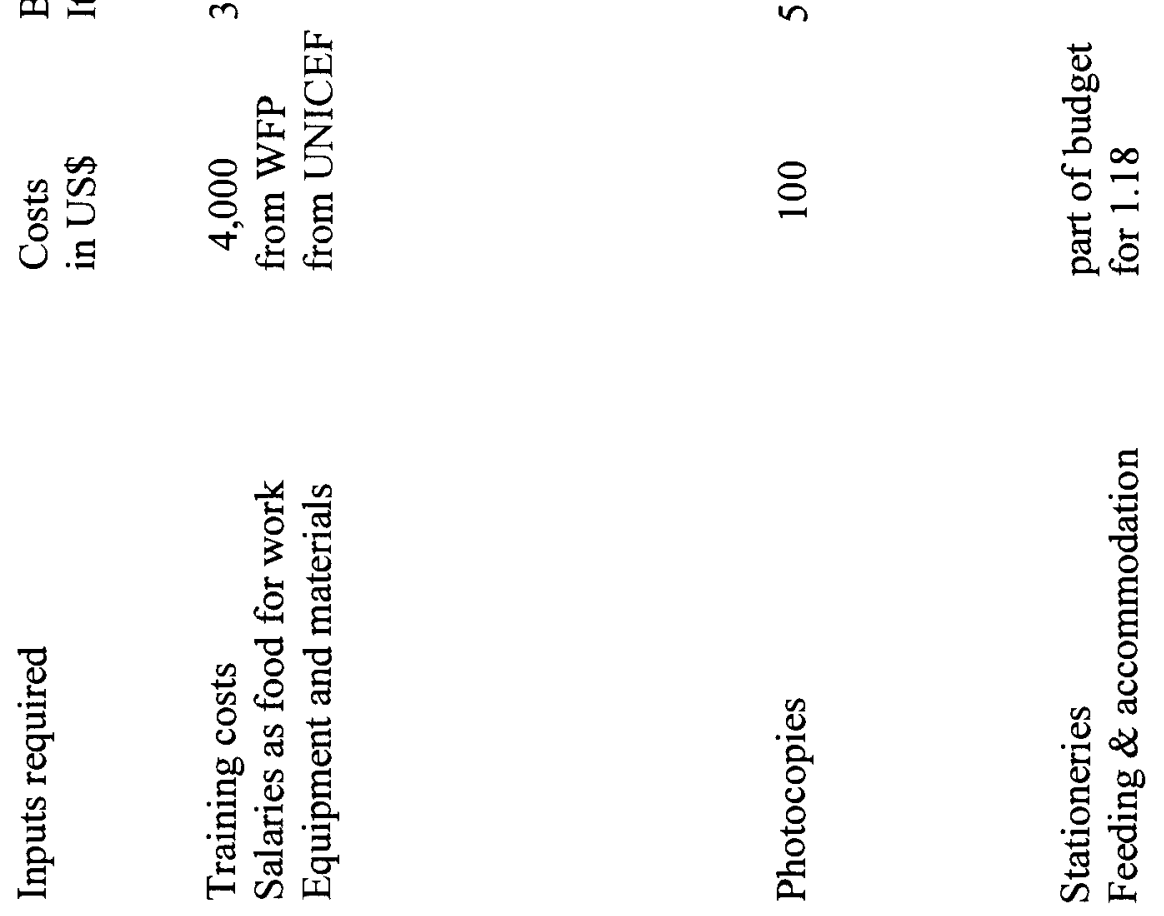

咅言高

咅产

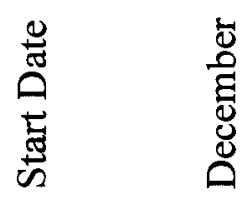

章 导

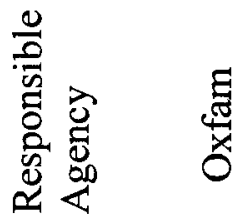

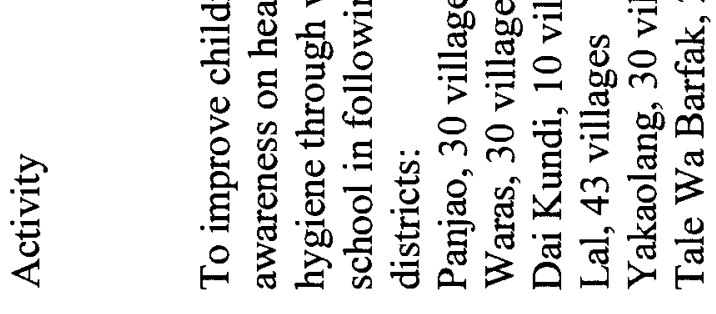

䒝告

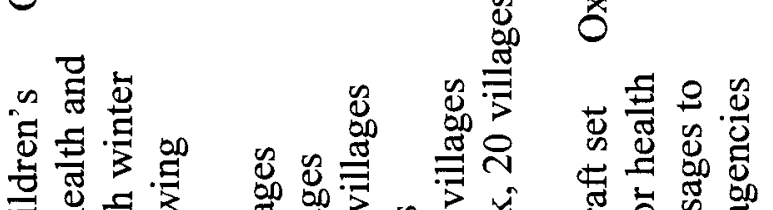

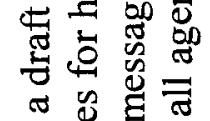

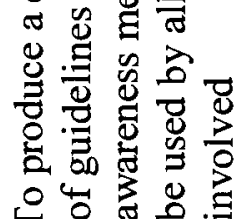

$\dot{z} \quad \infty$

กิ

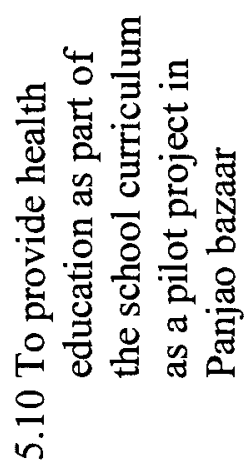



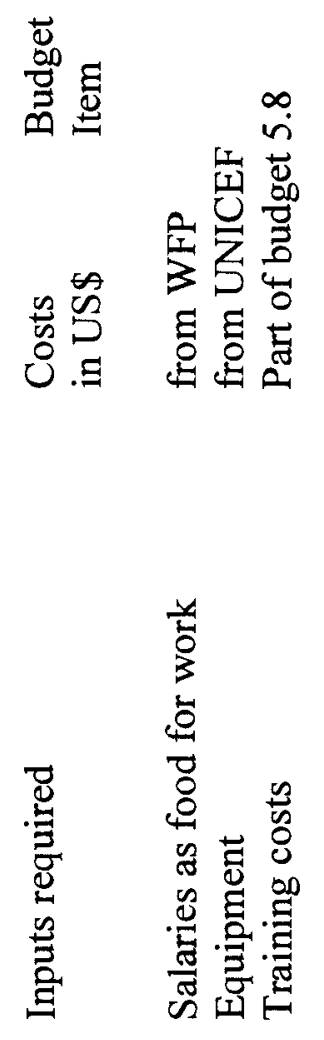

劳 吉

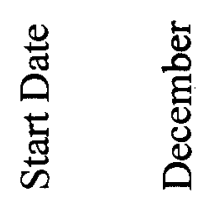

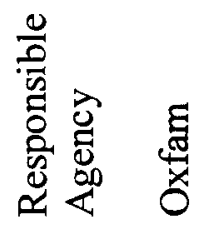

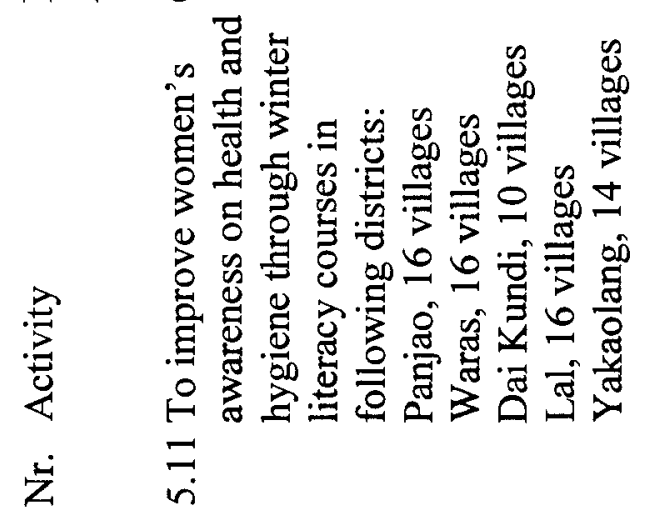

